\title{
Knowledge attitude and practice of type 2 diabetic patients in a tertiary care teaching hospital in India
}

\author{
Ravi Kant and Vinita Thapliyal* \\ All India Institute of Medical Sciences, Department of Medicine, Rishikesh, Uttrakhand, India
}

\begin{abstract}
Objective: To assess the Knowledge, Attitude and Practice of type 2 diabetic patients at AIIMS Rishikesh.

Materials and methods: A cross-sectional study was done at the All India Institute of Medical Sciences (AIIMS) Rishikesh through a structured interview of 200 diabetes mellitus (Type 2) patients attending outdoor facility at the Institute. The questionnaire did not contain any questions that reveal the identity of the patients.

Results: A total of 200 outdoor patients were analyzed. Only $30 \%$ of the patients had BMI up to or below $23 \mathrm{~kg} / \mathrm{m}^{2}$. Out of 200 patients $64 \%$ were male $36 \%$ were female patients. $18 \%$ of the population did not know any complication regarding the diabetes. $78 \%$ of the population was literate. Only $50 \%$ of the population knew what diabetes is? $88 \%$ of the population still believes that bitter substances can control diabetes. $80 \%$ of the population thinks that insulin should be avoided as it is habit forming. Misconceptions were quite common among the population regarding diet, insulin and diabetes. This highlights the urgent need for better health information to the patient through large scale awareness programmes so as to change the attitude of our public regarding diabetes as India being the world capital.

Conclusions: This study showed that there was poor knowledge, attitude and practice about the diabetes which calls for immediate action and education by skilled health care providers.
\end{abstract}

\section{Introduction}

Diabetes mellitus is a metabolic disorder of multiple etiological factors characterized by chronic hyperglycemia with disturbance of carbohydrate metabolism which resulted from either insufficient insulin secretion, resistance to the action of Insulin or both $[1,2]$. International diabetes federation's report described that 382 million had diabetes in the year 2013 and it was estimated to reach 592 million in the year 2035. Diabetes mellitus is classified in to type I(IDDM), type 2 (NIDDM) and Gestational Diabetes Mellitus(GDM) type I being characterized by insulin deficiency which needs daily administration of insulin. Type 2 diabetes mellitus results from the body's ineffective use of insulin while gestational diabetes is hyperglycemia with onset or first recognition during pregnancy [3,4] Participation of patients is very crucial in the management of diabetes mellitus as medications alone aren't enough to manage the disease without different nonpharmacological measures taken [5,6]. Prevalence of diabetes mellitus is increasing globally, [7] more so in developing countries like India due to rapid urbanization $[8,9]$.

\section{Materials and methods}

Subjects and sampling: 200 Type 2 diabetic patients seen sequentially at the medicine OPD of AIIMS Rishikesh to assess the knowledge, attitude and practice of diabetes mellitus patients towards the disease.

Data collection: Data was collected through a structured interview with patients attending the outpatient door of the institute during the study period from the November 2014 to January 2015.These included the newly diagnosed Type 2 diabetes mellitus patients and medicine OPD or referred from within and outside institute for treatment of diabetes mellitus. The exclusion criteria precluded patients who were not physically or mentally able to conduct the interview. In the present study 200 patients who fulfilled the inclusion criteria and were willing to participate in the study were interviewed. Furthermore the data collected through the interviews was kept confidential and used strictly for the purpose of the study.

\section{Characteristics}

Body mass index: As per WHO patients those have a BMI between $18.5-23 \mathrm{~kg} / \mathrm{m}^{2}$ considered normal, those having BMI between $24-27 \mathrm{~kg} /$ $\mathrm{m}^{2}$ were considered overweight and above $27.5 \mathrm{~kg} / \mathrm{m}^{2}$ obese.

Assessment of knowledge: A questionnaire was prepared to assess the knowledge of the patients regarding the diabetes having content about Diet, Insulin and Diabetes and its complications.

Diet and Exercise practice: Diet was assessed by asking about the major food groups taken by the patient. Exercisepractice was assessed by enquiring about the nature of exercise done.

\section{Results}

Characteristics of the subjects: The $64 \%$ of the patients were male and $36 \%$ of the patients were female. The mean age was 50 years and the mean duration of the disease is 9.7 years. The $62 \%$ of the patients

Correspondence to: Vinita Thapliyal, All India Institute of Medical Sciences, Department of Medicine, Rishikesh, Uttrakhand, India, E-mail: Vinita.thapliyal22@gmail.com

Key words: diabetes mellitus, knowledge, attitude, practice, patients

Received: December 03, 2014; Accepted: January 16, 2015; Published: January 20, 2015 
had family income $>50,000$ in a year. The $78 \%$ of the population was illiterate. The source of information for the entire population was doctor hence there by meaning lack of awareness by other health care provider (Table 1).

Weight status: It is worrisome that only $30 \%$ of the populations were having BMI between 18-23 which is considered to be normal for Asian population because of having thrifty phenotype. 53\% of the populations were overweight having BMI between $24-30$ and $17 \%$ of the populations were having $\mathrm{BMI}>30$ (Tables 2-7).

Knowledge regarding the complications of diabetes: The population has poor knowledge regarding the complications of diabetes. $18 \%$ of the population didn't know any kind of complications regarding the diabetes. Only $4 \%$ of the population knows that diabetes can affect proper functioning of heart.

Assessment of knowledge: The overall assessment regarding the knowledge of diabetes was satisfactory $50 \%$ of the population knows what diabetes is and what causes diabetes? But the population had poor knowledge regarding the features of diabetes.

Table 1. Characteristics of population ( $\mathrm{N}=200)$.

\begin{tabular}{|c|c|}
\hline Variables & Percentage $(n=200) p>0.05$ \\
\hline Age(years) Mean \pm SD & $50 \pm 9.32$ \\
\hline Mean duration of the disease (years) & 9.7 \\
\hline \multicolumn{2}{|l|}{ Gender Distribution } \\
\hline Male & 64 \\
\hline Female & 36 \\
\hline \multicolumn{2}{|l|}{ Work } \\
\hline Own Occupation & 16 \\
\hline Student & 3 \\
\hline House wife & 23 \\
\hline Service & 42 \\
\hline Labor & 16 \\
\hline \multicolumn{2}{|l|}{ Annual Income } \\
\hline$<20,000$ & 18 \\
\hline $20,000-50,000$ & 20 \\
\hline$>50,000$ & 62 \\
\hline \multicolumn{2}{|l|}{ Source of Information } \\
\hline Doctor & 100 \\
\hline Dietician & - \\
\hline Media & - \\
\hline Internet & - \\
\hline Some other source & - \\
\hline \multicolumn{2}{|l|}{ Education } \\
\hline Illiterate & 22 \\
\hline Primary & 18 \\
\hline Secondary/Middle & 24 \\
\hline Graduate & 26 \\
\hline Postgraduate & 10 \\
\hline
\end{tabular}

Table 2. Body mass index of population $(\mathrm{N}=200)$

\begin{tabular}{|c|c|}
\hline BMI & Percentage \\
\hline $18-23$ & 30 \\
\hline $24-30$ & 53 \\
\hline$>30$ & 17 \\
\hline
\end{tabular}

Table 3. Knowledge regarding complications of diabetes $(\mathrm{N}=200)$

\begin{tabular}{|c|c|}
\hline Complications & Percentage \\
\hline Heart & 4 \\
\hline Renal & 20 \\
\hline Retinopathy & 8 \\
\hline Stroke & 20 \\
\hline Neuropathy & 30 \\
\hline Don't Know & 18 \\
\hline
\end{tabular}

Table 4. Assessment regarding diabetes and its features $(\mathrm{N}=200)$.

\begin{tabular}{|l|c|}
\hline Questions to assess knowledge & Correct answer percentage \\
\hline What is diabetes? & 50 \\
\hline What causes diabetes? & 54 \\
\hline Can diabetes be cured? & 12 \\
\hline How can diabetes be detected? Features of diabetes & 26 \\
\hline Polyuria & 30 \\
\hline Polyphagia & 8 \\
\hline Weight Loss & 6 \\
\hline Numbness in feets & 18 \\
\hline Can be asymptomatic & 10 \\
\hline Excessive Thirst & 30 \\
\hline Don't know & 16 \\
\hline & \\
\hline & \\
\hline & \\
\hline & \\
\hline
\end{tabular}

Knowledge of exercise and diet: Misconception about the diet is prevailing $88 \%$ of the population still believes in the fact that bitter substances can cure diabetes. Half the population believes that both exercise and diet modification should be to control the diabetes.-

Knowledge of drug therapy: The population had very poor 
Table 5. Knowledge of exercise and $\operatorname{diet}(\mathrm{N}=200)$.

\begin{tabular}{|l|c|}
\hline Knowledge of exercise and diet & Percentage \\
\hline What shoud be done to control DM? & 32 \\
\hline Exercise & 18 \\
\hline Diet Modification & 50 \\
\hline Both & 16 \\
\hline Exercise should be done only by obese? & 88 \\
\hline Bitter substances can cure diabetes? & \\
\hline
\end{tabular}

Table 6. Knowledge regarding OHA, insulin, hebal drugs $(\mathrm{N}=200)$.

\begin{tabular}{|l|c|}
\hline Knowledge of drug therapy & Percentage \\
\hline Once DM is control drug should be stop? & 66 \\
\hline Drug is more important than diet control? & 36 \\
\hline Herbal drugs are better? & 18 \\
\hline Insulin Should be avoided? & 80 \\
\hline Insulin is habit forming? & 90 \\
\hline
\end{tabular}

Table 7. Attitude and practice towards diabetic care, eating practices and health care $(\mathrm{N}=200)$.

\begin{tabular}{|l|c|}
\hline Respondent attitude and practice & Percentage \\
\hline Who is responsible for your diabetic care? & 48 \\
Yourself & 26 \\
Doctor & 6 \\
Family & 72 \\
Do you include fruits? & 90 \\
Do you include GLV's in your diet? & 32 \\
Do you have glucometer? & 36 \\
Do you check your sugar regularly? & 44 \\
Do you check your foot regularly? & 70 \\
\hline Do you take herbal drugs? & \\
\hline
\end{tabular}

knowledge about the drug therapy $80 \%$ of the population believes that insulin should be avoided and $90 \%$ believe that it is habit forming. Hence majority of the population refuse Insulin in spite of uncontrolled sugar level showing lack of knowledge and awareness regarding the disease.

Attitude and practice towards diabetes: The overall attitude and practice towards diabetes was below satisfaction. Only $26 \%$ of the population still believes that doctor is responsible for their diabetic care. Only $36 \%$ of the populations were checking their sugar regularly and $32 \%$ of the population had glucometer at their home. $70 \%$ of the populations were taking herbal medicine for one or the other purpose.

\section{Discussion}

Most studied regarding epidemiology and prevalence of diabetes were conducted from south India [10-13] and very few studies from north India [14]. There is no studies regarding KAP available for Uttrakhand and western Uttar Pradesh hence, this study is an attempt to gather the data regarding the same.

The management of DM not only requires the prescription of the appropriate nutritional and pharmacological regimen by the physician but also intensive education and counselling of the patient [15]. This finding emphasizes that the average knowledge levels are low despite of $78 \%$ literacy rate in communities with higher diabetes prevalence [16]

\section{References}

1. Alberti KG, Zimmet PZ (1998) Definition, diagnosis and classification of diabetes mellitus and its complications. Part 1: diagnosis and classification of diabetes mellitus provisional report of a WHO consultation. Diabet Med 15: 539-553. [Crossref]

2. Sicree R, Shaw J, Zimmet P. The Global Burden: Diabetes and Impaired Glucose Tolerance. IDF Diabetes Atlas. $4^{\text {th }}$ edn.

3. International Diabetes Federation, IDF Diabetes Atlas 2013; $6^{\text {th }}$ edn.

4. World Health Organization. Diabetes Fact sheet 2013; No. 312.

5. Siminerio L, Kulkarni K, Pearson T, Rodbard H, Meece J, et al. (2011) Strategies for Insulin Injection Therapy in Diabetes Self-Management: American Association of Diabetes Educators.

6. Clifford RM, Davis WA, Batty KT, Davis TM (2005) Effect of a pharmaceutical care program on vascular risk factors in type 2 diabetes: the Fremantle Diabetes Study. Diabetes Care 28: 771-776. [Crossref]

7. Kuller LH (1997) Dietary fat and chronic diseases: epidemiologic overview. J Am Diet Assoc 97: S9-S15. [Crossref]

8. Grol ME, Halabi YT, Gerstenbluth I, Alberts JF, O'Niel J (1997) Lifestyle in Curaçao. Smoking, alcohol consumption, eating habits and exercise. West Indian Med J 46: 8-14. [Crossref]

9. Ramachandran A, Snehalatha C, Baskar AD, Mary S, Kumar CK, et al. (2004) Temporal changes in prevalence of diabetes and impaired glucose tolerance associated with lifestyle transition occurring in the rural population in India. Diabetologia 47: 860-865. [Crossref]

10. Ramachandran A, Snehalatha C, Kapur A, Vijay V, Mohan V, et al. (2001) High prevalence of diabetes and impaired glucose tolerance in India: National Urban Diabetes Survey. Diabetologia 44: 1094-1101. [Crossref]

11. Kutty VR, Soman CR, Joseph A, Pisharody R, Vijayakumar K (2000) Type 2 diabetes in southern Kerala: variation in prevalence among geographic divisions within a region. Natl Med J India 13: 287-292. [Crossref]

12. Ramachandran A, Jali MV, Mohan V, Snehalatha C, Viswanathan M (1988) High prevalence of diabetes in an urban population in south India. BMJ 297: 587-590. [Crossref]

13. Ramachandran A, Snehalatha C, Latha E, Vijay V, Viswanathan M (1997) Rising prevalence of NIDDM in an urban population in India. Diabetologia 40: 232-237. [Crossref]

14. Nuttall FQ (1993) Carbohydrate and dietary management of individuals with insulinrequiring diabetes. Diabetes Care 16: 1039-1042. [Crossref]

15. Viral N Shah, Kamdar PK, Nishit Shah (2009) Assessing the knowledge, attitudes and practice of type 2 diabetes among patients of Saurashtra region, Gujarat. Int $J$ Diabetes Dev Ctries 29: 118-122. [Crossref]

16. Tham KY, Ong JJ, Tan DK, How KY (2004) How much do diabetic patients know about diabetes mellitus and its complications? Ann Acad Med Singapore 33: 503-509. [Crossref]

Copyright: (C2015 Kant R. This is an open-access article distributed under the terms of the Creative Commons Attribution License, which permits unrestricted use, distribution, and reproduction in any medium, provided the original author and source are credited. 